\title{
Preparation of An Information Booklet and Its Impact on Staff Nurses Regarding Their Legal Responsibilities in Selected Hospitals of Kashmir Valley
}

\author{
R. Haffiz ${ }^{1}$, N. H. Reshi ${ }^{2}$ \\ ${ }^{1}$ Nursing Supervisor, SKIMS Medical College and Hospital, Bemina Srinagar, Jammu \& Kashmir \\ ${ }^{2}$ Assistant Professor, Government College of Nursing, GMC Srinagar, Jammu \& Kashmir
}

\begin{abstract}
In order to study the knowledge of staff nurses regarding their legal responsibilities, an experiment was conducted in Kashmir valley in which sixty nurses working in selected hospitals were questioned through a standard questionnaire. An information booklet containing adequate information regarding various aspects of legal responsibilities of staff nurses was prepared and distributed among the nurses. The study revealed that the mean post test knowledge scores of staff nurses (34.48) was higher than their median pre test knowledge scores (21.16). It was observed that all the subjects achieved higher scores in the post-test (34.48) than in the pre-test (21.16) suggesting the information booklet was effective in increasing the knowledge of each subject. The findings also revealed that the post test scores were homogenous $(S . D=3.558)$ than the pre test scores $(S . D=4.032)$. The study suggested that information booklet was effective in enhancing the knowledge of staff nurses.
\end{abstract}

Keywords: staff nurses, legal responsibilities, questionnaire, information booklet

\section{Introduction}

These days" nurses are acutely aware of the need to understand the legal environment in which they practice. Ever shrinking resources, shorter lengths to stay, high-acuity patients, the availability of more complex information, and the use of technology means the nurses must understand the legal rights inherent to them by their practice. These legal aspects include the legal environment, regulation of nursing practice, standards of care, prevention of malpractice, professional liability, insurance and issues related to nurses as witness and when refusing an assignment.

A nurse working as per the professional standards can avert many of the risks and legal suits. Nurses must know the law that governs her profession to avoid law suits against her. The knowledge of legal responsibilities is integral with the expanding clinical role, and a logical application of the planned, systematic and focused care, which should be the goal of modern nursing. (Shaw 1998).

Today"s patient is viewed as an active member of health team rather than passive recipient of care. Average citizen today is much more knowledgeable about complicated mechanism of human body. He knows that he has right to question the treatment he is being given, in this statement have to say that to be kept informed of his progress. There has been an active and growing consumer movement in the health field. Increasing public awareness of health issues and rising cost of health services are some of the factors controlling to this movement. The patient wants to be involved in the treatment decision.

\section{Conceptual Frame}

The conceptual frame work for the study was based on systems model. The experimental research approach with one group pre-test and post test design was used. Simple random sampling technique was employed to select the sample subjects. A structured knowledge questionnaire with 39 knowledge items and attitude questionnaire containing 42 items for attitude assessment were used.

Content validity of the tools and information booklet was established by 9 experts. Reliability was established by KR 20 method and the tool was found reliable with reliability Coefficient of 0.7 . The reliability of the attitude questionnaire was established by test retest method which was found to be 0.85 . The data collected was analyzed using both descriptive and inferential statistics.

\section{Results and Discussion}

In the study majority (74\%) of the staff nurses belonged to the age group of $30-40$ years. $46 \% \& 44 \%$ of the staff nurses" ${ }^{\text {e }}$ professional education were Post-basic BSc. Nursing and GNM respectively. Majority (88\%) of the staff nurses had a working experience of 10-15 years. Also majority $(80 \%)$ of the staff nurses had not attended in-service education programme. All the staff nurses had not attended any in-service programme related to legal aspects. The mean pre-test knowledge score is 21.16 with a median 21.00 and S.D 4.032 against the maximum score of 39 . The mean post test knowledge score is 34.48 with a median of 35 and S.D.3.56 against a maximum score of 39. Mean post test knowledge scores (34.48) of staff nurses was found to be significantly higher than their mean pre-test knowledge scores (21.16), as evident from the ,t" value of $\mathbf{1 6 . 1 2}$ 


\section{International Journal of Science and Research (IJSR) \\ ISSN (Online): 2319-7064 \\ Index Copernicus Value (2013): 6.14 | Impact Factor (2014): 5.611}

suggesting that the knowledge of staff nurses on legal responsibilities increased after administering the information booklet. The Fishers Exact test between pre -test knowledge scores and age was found to be statistically insignificant revealing there was no significant relationship between pre test knowledge scores and age. The Fishers Exact test between pre -test knowledge scores and professional qualification was found to be statistically insignificant revealing there was no significant relationship between pre test knowledge scores and professional qualification. The Fishers test between pre test knowledge scores and clinical experience was found to be statistically insignificant revealing there was no significant relationship between pre test knowledge scores and clinical experience.

Table 1: Frequency and percentage distribution of staff nurses by demographic characteristics $\mathrm{n}=50$

\begin{tabular}{|c|c|c|c|}
\hline S/no & $\begin{array}{c}\text { Socio-demographic } \\
\text { variables }\end{array}$ & Frequency & $\begin{array}{c}\text { Percentage } \\
(\%)\end{array}$ \\
\hline 1. & $\begin{array}{l}\text { Age (in years) } \\
\text { - } 20-30 \\
\text { - } 31-40 \\
\text { - Above } 40 \\
\end{array}$ & $\begin{array}{l}00 \\
37 \\
13 \\
\end{array}$ & $\begin{array}{l}00 \\
74 \\
26 \\
\end{array}$ \\
\hline 2. & $\begin{array}{l}\text { Gender } \\
\text { - Male } \\
\text { - Female } \\
\end{array}$ & $\begin{array}{l}00 \\
50\end{array}$ & $\begin{array}{c}00 \\
100\end{array}$ \\
\hline 3. & $\begin{array}{l}\text { Marital status } \\
\text { - Married } \\
\text { - Unmarried }\end{array}$ & $\begin{array}{l}44 \\
06\end{array}$ & $\begin{array}{l}88 \\
12\end{array}$ \\
\hline 4. & $\begin{array}{l}\text { Professional qualification } \\
\text { - GNM } \\
\text { - Post-basic B.Sc Nsg. } \\
\text { - B.Sc Nursing }\end{array}$ & $\begin{array}{l}23 \\
22 \\
05\end{array}$ & $\begin{array}{l}46 \\
44 \\
10\end{array}$ \\
\hline 5. & $\begin{array}{l}\text { Clinical experience(years) } \\
\text { - } 2-5 \\
\text { - } 6-10 \\
\text { - } 11-15 \\
\text { - Above } 15\end{array}$ & $\begin{array}{l}00 \\
04 \\
44 \\
02\end{array}$ & $\begin{array}{c}00 \\
8 \\
88 \\
04\end{array}$ \\
\hline
\end{tabular}

Table 2: Mean, Mean difference, standard deviation, of pre test and post test knowledge scores of staff nurses, $n=50$

\begin{tabular}{|c|c|c|c|c|c|}
\hline $\begin{array}{c}\text { Knowledge } \\
\text { score }\end{array}$ & $\begin{array}{c}\text { Range of } \\
\text { obtained score }\end{array}$ & Mean & $\begin{array}{c}\text { Mean } \\
\text { difference }\end{array}$ & Median & S.D \\
\hline Pre-test & $3-50$ & 21.16 & & 21 & 4.032 \\
\hline Post-Test & $35-50$ & 34.48 & 13.32 & 35 & 3.558 \\
\hline
\end{tabular}

Maximum possible score : 39

The data in the table 2 indicates that the mean post test knowledge scores of staff nurses (34.48) was higher than their median pre test knowledge scores ( 21.16) .It is observed that all the subjects achieved higher scores in the post -test (34.48) than in the pre-test (21.16) suggesting the information booklet was effective in increasing the knowledge of each subject. The findings also revealed that the post test scores were homogenous ( $\mathrm{S} . \mathrm{D}=3.558)$ than the pre test scores $(S . D=4.032)$.It suggests that information booklet was effective in enhancing the knowledge of staff nurses. The data in table 4 shows that the knowledge, pretest range of obtained score is 3-50, its mean 21.16 and mean difference 13.32, and standard deviation 4.032 score .The post- test range of obtained score 35-50 score, mean 34.48, mean difference 13.32, median 35 and standard deviation 3.558 .The standard deviation of post test is 3.558 which is less than pre test indicating that the group is now more homogenous with the mean and median increasing from 21.16 to 34.48. This shows an increase in the knowledge of the group.

Table 3: Fishers Exact Test between Pre-Test Knowledge Scores of the staff nurses and their Selected Factors $n=50$

\begin{tabular}{|c|c|c|c|c|c|c|}
\hline \multirow[t]{3}{*}{ S.No } & \multirow[t]{3}{*}{ Selected Variables } & \multicolumn{4}{|c|}{ Knowledge scores } & \multirow[t]{3}{*}{ 'p' value } \\
\hline & & \multicolumn{2}{|l|}{ Adequate } & \multicolumn{2}{|l|}{ Inadequate } & \\
\hline & & Frequency & percentage & Frequency & percentage & \\
\hline \multirow[t]{4}{*}{1} & $\begin{array}{l}\text { Age } \\
\text { - 21-30years }\end{array}$ & 0 & $(0 \%)$ & 0 & $(0 \%)$ & \multirow{4}{*}{$<0.001$} \\
\hline & - 31-40 years & 02 & $(5.4 \%)$ & 35 & $(96.6 \%)$ & \\
\hline & - Above 40 years & 01 & $(7.7 \%)$ & 12 & $(92.3 \%)$ & \\
\hline & Total & 3 & $94.0 \%$ & 47 & $6.0 \%$ & \\
\hline \multirow[t]{4}{*}{2} & $\begin{array}{l}\text { Professional Education } \\
\text { - GNM }\end{array}$ & 02 & $8.7 \%$ & 21 & $91.3 \%$ & \multirow[t]{4}{*}{$<0.001$} \\
\hline & - Post-basic B Sc Nursing & 01 & $4.5 \%$ & 21 & $95.5 \%$ & \\
\hline & - B Sc Nursing & 00 & $0.0 \%$ & 05 & $100 \%$ & \\
\hline & Total & 03 & $06 \%$ & 47 & $94 \%$ & \\
\hline \multirow[t]{5}{*}{3} & $\begin{array}{l}\text { Clinical Experience } \\
-2-5 \text { years }\end{array}$ & 00 & $0.0 \%$ & 00 & $0.0 \%$ & \multirow[t]{5}{*}{$<0.001$} \\
\hline & - 5-10years & 00 & $0.0 \%$ & 4 & $100 \%$ & \\
\hline & - $10-15$ years & 3 & $6.8 \%$ & 41 & $93.2 \%$ & \\
\hline & - Above 15 years & 0 & $0.0 \%$ & 2 & $100 \%$ & \\
\hline & Total & 3 & $6 \%$ & 47 & $94 \%$ & \\
\hline
\end{tabular}

Insignificant at 0.05 level of significance $\boldsymbol{p}<\mathbf{0 . 0 0 1}$. Maximum Possible scores $=50$
The present study corroborates with several workers, Paul Prema (2007), conducted a study to assess knowledge of nurses regarding legal responsibilities towards patient care 


\section{International Journal of Science and Research (IJSR) \\ ISSN (Online): 2319-7064 \\ Index Copernicus Value (2013): 6.14 | Impact Factor (2014): 5.611}

in a selected hospital, Pune, Maharashtra. She revealed that there were significant association between level of pretest knowledge and their professional qualification; she also found that informational booklet was effective in increasing the knowledge of subjects in all the areas of legal responsibilities of nurses related to patient care. She also reported that 865 of nurses believed that booklet was a good source of learning and $98 \%$ nurses believed that booklet should be made available to all the staff nurses. A copy of booklet may be provided to all nurses during orientation.

Agyapong et al, (2008), conducted a study on "Medical confidentiality versus disclosure: ethical and legal dilemmas". The study was carried out in Beaumont hospital, Dublin, Ireland. A case is described of a fifty year old single man who made disclosures about criminal sexual practices during assessment. In common practice with other professional men, a doctor is bound to not disclose patients information without the consent of his patient. Information which he has gained in his professional capacity other than in exceptional circumstances. We discuss the ethical and legal considerations surrounding issues of medical confidentiality and the dilemma that sometimes clinicians face, when they feel obliged, in the public interest, to disclose information they have gained in confidence .Breach of confidences can have deleterious consequences: particularly for the Doctor- patient relationship, but failure to disclose in some situations could have serious implications for the well-being of the wider society .Doctors should be aware of the basic principles of confidentiality and the ethical and legal frame work around which they are built.

La Duke, Sharon (2000), In a study it was found that over 5000 nurses are disciplined in the country annually for professional misconduct and the number is increasing. The survey examined the perception and experiences of 33 nurses in New York state who were disciplined for professional misconduct in 1988. The investigator suggests the need for strategies that can help nurses to reduce their chances of being accused of malpractice.

Renjitha Rajesh (2006) conducted a study to find out the level of satisfaction of nursing care service provided to Bhopal gas victims and found that very less percentage of gas victims were satisfied with the physical care provided by nurses to them. She recommended that further studies are needed to find out level of satisfaction in regards to other areas of nursing care.

Mc Hughi (2003), states that the health professionals must be familiar with regulations and status addressing privacy and confidentiality issues. The nurses must be aware of specific limitations and exceptions to confidentiality. To ensure employee trust, nurse must maintain their ethical and legal responsibility to act morally when making decisions to confidentiality.

Binoy Sija (2005), conducted an evaluative study to evaluate the effectiveness of an informational booklet in increasing the knowledge of nurses regarding legal responsibilities . She found deficit of knowledge among nurses regarding legal responsibilities and found that the booklet was effective in increasing the knowledge of nurses. She recommended that study can be replicated in other hospitals.

\section{Conclusion}

The findings revealed that the nurses had inadequate knowledge regarding legal responsibilities. It was also found that there was a significant relationship between knowledge of staff nurses and their professional qualification as well as their clinical experience. Therefore, all the nurses should be aware of the legal responsibilities by in-service education programme or orientation programmes. The nurses who have very less clinical experience as well as fresh graduates should be oriented to the hospital policies and guidelines. They should be closely supervised on their legal responsibilities. The information booklet was found an effective method in increasing the knowledge and improving the attitude of the staff nurses regarding legal responsibilities. The nurses found the information booklet, a very useful learning aid. They appreciated the booklet and expressed that the booklet was effective. It also helped them in learning many legal terms like tort, malpractice etc.

\section{Recommendations}

On the basis of the findings of the study, it is recommended that a similar study can be replicated on larger samples of staff nurses of different hospitals for generalization of the findings. Similar study can be replicated on larger samples of staff nurses of different hospitals for generalization of the findings. Further a similar study can be done to evaluate the effectiveness of booklet regarding legal responsibilities in community nursing care settings. Also a survey can be conducted to know the opinion of the staff nurses regarding legal responsibilities.

\section{References}

[1] Anthony, M.K. et al, (2000) "Factors influencing outcomes after delegation to unlicensed assistive personnel". Journal of nursing administration. 12 (3): 474-481.

[2] Barnabas, Seema, S.R. (2004). "Study to Assess Knowledge of legal responsibility in patient care Among Nursing Graduates". The nursing journal of India. XCV (4) $90-91$.

[3] Bridgit D. (2007). "Mental capacity Act", British journal. 16(21): 1328-1329.

[4] Burns, H. (2004). "Patient safety Developing policies for Engagement in the prevention of Harms to patients". Journal of professional Nursing”. 20 (1): 45-75.

[5] Crigin, M. et al (2004). "Ethical and Legal Issues in Conducting Nursing Research via the Internet". Journal of Professional Nursing. 20 (1): 68-73.

[6] Davis A.J. and Jameton A. (1987). "Nursing and Medical students attitudes towards nursing disclosure of information of patients". journal of advanced Nursing. 12 (10): 691-698.

[7] Woogra, G.R. (2005). “ An ethnographic study to determine the extent to which patient's right to privacy and dignity are respected". Journal of nursing standard. 18(18): 33-37. 


\section{International Journal of Science and Research (IJSR) \\ ISSN (Online): 2319-7064}

Index Copernicus Value (2013): 6.14 | Impact Factor (2014): 5.611

[8] Yates, B.C et al. (2009). "Testing An Alternative Informed consent process". journal_of Nursing Research. 58 (2): 135-139.

[9] Abraham, D.S. (2004). "Laws on Hospital Administration, Chennai”: B.L. publications PVT. LTD. pp 112-169. 